\title{
The Role of the Jordanian High Schools in Deepening Good Citizenship among their Students
}

\author{
Dr. Reem Yousef Saleh Prof. Dr. . Mohammad Saleem Al-Zboon \\ University of Jordan
}

\begin{abstract}
The study aims to identify the role of Jordanian secondary schools in deepening good citizenship among their students. It also examines the obstacles facing Jordanian secondary schools in deepening good citizenship among their students. To achieve the objectives of the study, the descriptive survey approach has been used for its suitability of the nature of this study, where a questionnaire was designed and distributed to a 180-teacher study sample from the Jordanian government schools. The results of the study show that the degree of the role of Jordanian high schools in deepening good citizenship among their students from the standpoint of the study sample is generally medium. It also shows that the school principal's role in developing good citizenship ranked first and the teacher's role in developing good citizenship ranked second, followed by the role of activities and courses in developing good citizenship in the last rank. In light of the results of the study, the researchers recommend working on creating an appropriate learning environment that enables teachers to teach citizenship issues to students and provide school libraries with educational books and brochures that deepen and root citizenship values to deal with all segments of society.
\end{abstract}

Keywords: citizenship, Jordan, High School, Students

DOI: $10.7176 / \mathrm{JEP} / 11-6-05$

Publication date: February $29^{\text {th }} 2020$

\subsection{Introduction}

The contemporary era is characterized by features that distinguish it from past times, in which financial values overwhelmed spiritual and moral values and dominated several aspects of life these days. Arab societies have recently witnessed a set of rapid changes in the cultural, social, political and economic aspects, leading to eliminate the meanings of human life and the disturbance of the value system among individuals and societies. Since the values elevate the human being and are considered the highest levels among the most important things in the life of nations and peoples, societies are trying to educate their members on the value system that they believe in so that they are preferred and applicable to them by making them imitate and practice them strongly so that they are among their personalities from the time of their birth. On the other hand, the issue of aesthetic values is considered one of the most important topics that occupy many segments of any society due to its sensitivity in building generations so that the value system followed is a system based on the conviction of individuals and groups (Khazaleh, 2010).

The world witnessed many changes and developments in recent years such as technological development, information revolution, scientific progress, an increase in the level of access to information from outside the school's scope and students 'access to different sources to obtain information. This has imposed on the educational system in general and the school in particular to play non-traditional roles that have been in the past the basis for the educational process. The school has become responsible for performing new roles imposed by these changes and developments in the world, as it became imperative for it, with its human cadres and financial resources, to address the new roles imposed on it and contribute to finding a generation of students who can face contemporary and future challenges (Matar, 2011).

As education is a profession that has great sacredness, the teacher is the teacher, educator, brother and friend, where not everyone can assume this great responsibility or mastery of this profession without having these qualities, sensing the fear of God and knowing the great responsibility that he will be held accountable for before his Lord and himself. So, he must perform his profession and tasks completely and does not underestimate it. Prophet Muhammad (Peace Be Upon Him) urged all people to do his work as required because God who perfectly completes his work, and imagine if this work is to raise and educate the new generation under the rules of God to achieve the interest of society and lead to its growth and development (Asongu, 2007).

Education as a profession is one of the most important professions in our ancient or modern society, and it is considered a starting point in determining what is our future ambition from various disciplines. The education's profession develops your individual and collective capabilities and reveals your capabilities in certain areas and weaknesses in other areas, which enables you to determine what specialization suits you in high school and undergraduate level (Shweihat, 2019).

Education is the basis for the advancement of nations and its endeavor to distinguish among countries, as a nation, that can develop its educational system, is the most capable of achieving development in various applied and humanities. For this reason, developed countries are working to invest in their educational system, realizing 
that it is a successful way to catch up with scientific, theoretical, and laboratory progress and advance society (Sakran, 2016).

Janini (2009) shows the importance of education that emerges from the formation of a mature, rational, wellmannered character who is capable of producing, keeping pace with developments, and adapting to the spirit of the modern era. With that, the individual has achieved freedom, excellence, creativity and success in his life to build and improve his society, eliminate the multiple crises that exist in society, and make the society free from moral and social diseases.

The vision of the Jordanian educational system emerges from the formation of an educational community that is active, positive, and committed to the values, science, and excellence to reach globalization. As for its message, it focused on the formation of active citizens belonging to their homeland who contribute to the elevation of the world and humanity. Through the stipulated key values stipulated, the Jordanian educational system emphasized on good citizenship, responsibility, and building effective partnerships, as Jordanians are equal in political, social and economic rights and duties, and they differ from each other due to the extent of their giving to their community and their affiliation with it. The social foundations assert that the solidity and survival of the society are interest and a necessity for every individual, along with establishing a balance between the needs of the individual and the needs of the community and the cooperation of its members and their solidarity to achieve the public good and bear individual and social responsibility. They also assert that the progress of society depends on the organization of its members in a manner that preserves the national interest and that political and social participation is the right and duty of the individual towards his society (Aga and Assaf, 2015).

The importance of citizenship is highlighted in the solidity of society, its stability, its security, its advancement and then its progression and prosperity, as it enhances the affiliation and loyalty of its members to it. The interest in citizenship has increased in light of the knowledge and media revolution and the communications revolution, especially after the world witnessed many events and developments that foretell the loss of loyalty values of affiliation, national responsibility, and cultural individuality such as terrorism, the growing violence, the disintegration of social relations, the struggle of interests, and the infringement of others 'rights and freedoms (Hassan, 2013). Given that citizenship is part of the community's value system, the school has a major role in teaching students the values of citizenship, whether it is theoretical or practical through the elements of the educational process such as curricula, activities, and teaching methods to be good citizens in their society performing their national duties with full merit and competence (Issawy, 2019).

Based on the preceding, educating school students on the principle of citizenship has become very important, especially at present due to some contemporary international variables such as scientific and industrial development, globalization of markets, the information revolution, global media, globalization, and reluctance to social participation. Importantly, citizenship education moves the citizen from being a citizen by the article of the law to a case of being a positive citizen in his community in which he participates and obeys his law, performs his duties, and raises students to a sense of global responsibility to limit the impact of global issues on local affairs, especially in light of the novel concepts that imply globalization, such as global responsibility and global citizen. According to the previous argument, there is a dire need to study the role of high school in deepening good citizenship among its students. Against this, the problem of the study is to examine the role of high school in deepening good citizenship among students in Jordan.

\subsection{Problem of the Study}

Citizenship is a technique for building a citizen who can live in peace and tolerance with others based on sympathy, equal opportunities, and work to contribute to building the nation's development and preserving co-existence in it. For this, we find that the process of education and socialization carried out by the school forms the basis of forming citizenship as a distinct negative or positive behavioral pattern. Thus, it contributes to developing a feeling of belonging and positive participation through educational curricula and be an effective tool in establishing the foundations of citizenship. The school environment has a direct impact on achieving what is intended for national education and citizenship development, as the construct and quality of life within the school, as well as the formal curriculum with its planned materials and contents, affect the student and its development on citizenship.

Through the practical experience as a member of the local community in one of the Jordanian government schools and participation in the activities carried out by the school, the researchers note that there is a weakness in the school's role in developing and promoting the values of good citizenship. By reviewing some previous relevant studies such as Saadi's study ( 2018), and Shweihat (2019) whose main results show that there are some shortcomings concerning the content and nature of the curricula, methods, and tools of education and what the school is doing in developing and deepening good citizenship which helps in preserving public facilities and properties and ensuring the national interest.

\subsection{Questions of the Study}

In light of the problem of the study, the following questions are articulated: 
1. What is the role of Jordanian high schools in deepening good citizenship among their students from the standpoint of their teachers?

2. What are the obstacles that Jordanian high schools face in deepening good citizenship among their students from the standpoint of their teachers?

\subsection{Objectives of the Study}

In light of the questions of the study, the following objectives are formatted:

1. Identify the role of Jordanian high schools in deepening good citizenship among their students from the standpoint of their teachers.

2. Explore the obstacles that Jordanian high schools face in deepening good citizenship among their students from the standpoint of their teachers.

\subsection{Significance of the Study}

The significance of the current study is articulated in the results of this study to reveal the reality of the role of government secondary schools in Jordan in deepening citizenship among its students. It is hoped that the results of the current study will contribute to developing the role of schools in developing and deepening good citizenship for students. Also, the results of the study may lead the decision-makers at the Ministry of Education to reconsider the study plan and academic courses. Besides, the current research highlights an important issue in society, which is citizenship, as it is the main element in instilling the values of tolerance, volunteering, cooperation and social solidarity.

\subsection{Previous Studies}

Few Arab and foreign studies have been written on the aforesaid problem of the study. In his 2010 study, Son aimed at identifying the evaluation of citizenship education in secondary education in England from the viewpoint of teachers and students. The study adopted the descriptive approach using two tools: the first is a questionnaire, and the second is an interview applied to a sample of teachers and students in (18) schools. The results of the study showed that the way students acquire citizenship values affects the choice of appropriate methods to assess their citizenship because these methods are not related to academic content. The results also indicated that students' attitudes towards citizenship depend on the teacher himself.

Martin and Yap (2011) conducted a study aimed at identifying students' understanding of citizenship through educational paths. The study adopted the descriptive approach using the interview method and consisted of (62) male and female students distributed in (16) high schools. The study varied the students 'understanding of their role as citizens and showed that students have a lack of knowledge of their political and democratic rights. The results also showed that all students described citizenship in terms of their responsibilities towards the state, such as obeying laws and participating in voting amongst themselves. However, some students viewed the concept of citizenship is to maintain a clean environment. As for others, they have shown that a good citizen is the one who obeys the laws of his country and has a high level of confidence in the government, its institutions, and its role in ensuring the social welfare of citizens.

Share (2017) conducted a study aimed at identifying the role of the secondary school in Gaza Governorate in supporting the aspects of citizenship among its students from the viewpoint of teachers of humanities. To achieve the objective of the study, the researchers used the descriptive approach, along with a study of (163) questionnaires. The results of the study showed that there are no statistically significant differences at an average of $(0.05)$ between the responses of the teachers 'answers and the humanities' teachers related to strengthening aspects of citizenship that can be attributed to the gender variable. There are also no statistically significant differences at an average of $(0.05)$ between the average answers of teachers and humanities teachers related to strengthening aspects of citizenship that can be attributed to the variable of the educational qualification (Bachelors - Masters or higher).

Saadi (2018) conducted a study aimed at identifying the role of the school in promoting the values of digital citizenship among middle school students in the city of Makkah Al-Mukarramah. The school has a very important role in promoting the values of digital citizenship among middle school students. Besides, the results showed that there were no statistically significant differences in the responses of the research sample according to the gender variable and the variable of scientific experience, while it revealed the presence of statistically significant differences in the responses of the study sample according to the variable of nature of work for the benefit of supervisors in education offices.

Shweihat (2019) conducted a study aimed at identifying the role of faculties of educational sciences in Jordanian universities in developing the values of citizenship among students and identifying the differences in the role of faculties of educational sciences in developing citizenship values among students according to gender, academic level, and specialization. The study sample consisted of ( 538) Male and female students from five universities, as the questionnaire used a data collection tool, and the descriptive-analytical method was used. The results of the study showed that the degree of the role of educational science faculties in Jordanian universities in 
developing citizenship values among students was medium. The fields were in descending order according to its arithmetic means as follows: the values of tolerance and respect for others, affiliation, scientific values, and political values. The results showed that there are statistically significant differences at a certain level in the role of educational science faculties in Jordanian universities in developing citizenship values among students attributed to the gender variable on the total degree of the instrument and the benefit of females. The results also showed the absence of statistically significant differences due to the variable of the academic level on the total degree of the instrument.

\subsection{Operational Terms of the Study}

The following definitions have been adopted by the study:

Citizenship: it is defined as " A link between the individual and the land where he resides and benefits from its goods, and he is aware of his rights and duties towards the state" (Dwairi, 2017, p. 8)

\subsection{Methodology of the Study}

\section{Study methodology}

The descriptive survey method has been used to achieve the objective of the study which is to know the role of the Jordanian high school in deepening good citizenship among its students.

\section{Study population}

The study population consisted of all secondary school teachers in Amman Governorate.

\subsection{The study sample}

As for the study sample, it has been selected according to the random sample method, which gives each individual in the study population equal opportunities. The number of the sample population reached (180) members from secondary school teachers in West Amman schools as shown in table (1).

Table 1: Frequencies and Percentages According to the Study Variables

\begin{tabular}{|l|l|l|l|}
\hline \multirow{3}{*}{ Gender } & Categories & Frequencies & Percentage \\
\hline \multirow{3}{*}{ Educational Experience } & Male & 75 & 41.7 \\
\cline { 2 - 4 } & Female & 105 & 58.3 \\
\cline { 2 - 4 } & Less than 5 years & 36 & 20.0 \\
\cline { 2 - 4 } & 5 - Less than 10 years & 64 & 35.5 \\
\cline { 2 - 4 } Academic Qualification & 10 years and more & 80 & 44.5 \\
\hline & BA & 135 & 75.0 \\
\cline { 2 - 4 } & Postgraduate & 45 & 25.0 \\
\hline & Total & 180 & 100.0 \\
\hline
\end{tabular}

\section{Study Instrument}

To achieve the aims of the study, theoretical literature and previous studies that addressed good citizenship as Saadi study (2018) and other related studies have been reviewed.

\section{Instrument Validity}

To ensure the validity of the instrument, it was presented to a group of validators to check the degree of suitability of the items in terms of their formulation, appropriateness for the field, and the degree of their achievement of the goal for which they were set. The opinions of validators have been taken in terms of deletion, modification, and addition, and then the questionnaire was finalized.

\section{Instrument Reliability}

To ensure the reliability of the study instrument, the test-retest method was checked, and the reliability coefficient was calculated by the internal consistency method according to the Cronbach Alpha Formula. Table (2) shows the coefficient of internal consistency according to the Cronbach alpha equation and the return reliability for the fields and the instrument as a whole. These values are considered appropriate for this study. 
Table 2: The Internal Consistency Coefficient of the Cronbach Apha, the Return Reliability of the Fields, and the Total Degree

\begin{tabular}{|l|l|l|}
\hline Field & $\begin{array}{l}\text { Return } \\
\text { Reliability }\end{array}$ & $\begin{array}{l}\text { Internal } \\
\text { Consistency }\end{array}$ \\
\hline The role of the school principal in developing good citizenship & 0.85 & 0.79 \\
\hline The role of the teacher in developing good citizenship & 0.74 & 0.75 \\
\hline $\begin{array}{l}\text { The role of activities and courses in developing good } \\
\text { citizenship }\end{array}$ & 0.86 & 0.83 \\
\hline & 0.82 & \\
\hline
\end{tabular}

The criterion for checking the averages of the study tool was determined by dividing it into three levels: low, medium, and high according to the following formula:

Category: length $=$ Highest value of the substitute, the minimum value of the substitute / Number of levels

$$
1.33=(5-1) / 3
$$

Accordingly, the following criterion was used to check the responses of the study sample:

A low degree is less than 2.33 .

Medium Degree is 2.34 to 3.67 .

High class from 3.68 to 5.00

\subsection{Results and Discussion}

The First Question: what is the role of the Jordanian high school in deepening good citizenship for its students?

To answer this question, arithmetic means and standard deviations were calculated as shown in Table 3.

Table 3: Arithmetic Means and Standard Deviations of the Role of High School in Deepening Good Citizenship among its students in Descending Order According to the Arithmetic Mean

\begin{tabular}{|l|l|l|l|l|l|}
\hline No & Rank & Field & AM & SD & Level \\
\hline $\mathbf{1}$ & 1 & The role of the school principal in developing good citizenship & 3.4 & 1.11 & Medium \\
\hline $\mathbf{2}$ & 2 & The role of the teacher in developing good citizenship & 3.33 & 0.47 & Medium \\
\hline $\mathbf{3}$ & 3 & The role of activities and courses in developing good citizenship & 3.14 & 0.38 & Medium \\
\hline & & Total degree & 3.29 & .33 & Medium \\
\hline
\end{tabular}

Table (3) shows that the arithmetic means ranged between (3.40.3.14), where the field of the role of the school principal in developing good citizenship ranked first with the highest arithmetic mean of (3.40), while the field of the teacher's role in developing good citizenship ranked second with a mean of (3.33). However, the field of the role of activities and courses in developing good citizenship ranked last with a mean of (3.14), and the mean for the total degree was (3.29). The arithmetic means and standard deviations for the study sample estimations were calculated on the items of each field separately as follows:

The First Area: the role of the school principal in developing good citizenship

Table 4: Arithmetic Means and Standard Deviations related to the School Principal's Role in Developing Good Citizenship in Descending Order by Arithmetic Means

\begin{tabular}{|l|l|l|l|l|l|}
\hline No & Item & AM & SD & Rank & $\begin{array}{l}\text { Degree } \\
\text { Agreement }\end{array}$ \\
\hline $\mathbf{1 0}$ & $\begin{array}{l}\text { The principal directs students to respect, appreciate and } \\
\text { preserve books }\end{array}$ & 3.72 & 0.94 & 1 & High \\
\hline $\mathbf{2}$ & $\begin{array}{l}\text { The principal develops the value of the teacher's respect, } \\
\text { obedience, and following his directions. }\end{array}$ & 3.71 & 0.94 & 2 & High \\
\hline $\mathbf{4}$ & $\begin{array}{l}\text { The principal encourages learning, academic achievement, and } \\
\text { collaboration among students }\end{array}$ & 3.68 & 0.95 & 3 & High \\
\hline $\mathbf{5}$ & $\begin{array}{l}\text { The principal educates students about school systems and } \\
\text { regulations to develop their citizenship values }\end{array}$ & 3.68 & 0.95 & 4 & Medium \\
\hline $\mathbf{3}$ & $\begin{array}{l}\text { The principal forms student teams to participate in various } \\
\text { committees such as cleaning, library and canteen }\end{array}$ & 3.66 & 1.12 & 5 & Medium \\
\hline $\mathbf{7}$ & $\begin{array}{l}\text { The principal educates students about the need to take care of } \\
\text { public facilities and maintain their safety }\end{array}$ & 3.66 & 0.99 & 6 & Medium \\
\hline $\mathbf{1}$ & $\begin{array}{l}\text { The principal organizes open days to integrate with the } \\
\text { students }\end{array}$ & 3.47 & 1.15 & 7 & Medium \\
\hline $\mathbf{1 1}$ & $\begin{array}{l}\text { The principal and teacher aim to help students interact with } \\
\text { national events }\end{array}$ & 3.08 & 1.20 & 8 & Medium \\
\hline $\mathbf{8}$ & $\begin{array}{l}\text { The principal helps students to acquire the skills of managing } \\
\text { the cultural and social halls }\end{array}$ & 3.07 & 1.24 & 9 & Medium \\
\hline
\end{tabular}




\begin{tabular}{|l|l|l|l|l|l|}
\hline No & Item & AM & SD & Rank & $\begin{array}{l}\text { Degree } \\
\text { Agreement }\end{array}$ \\
\hline $\mathbf{9}$ & $\begin{array}{l}\text { The principal conducts specialized courses for teachers and } \\
\text { administrators related to citizenship values }\end{array}$ & 2.98 & 1.25 & 10 & Medium \\
\hline $\mathbf{6}$ & $\begin{array}{l}\text { The principal creates a group of students to enrich their } \\
\text { knowledge of the site and the systems }\end{array}$ & 2.72 & 1.20 & 11 & Medium \\
\hline & Total average & 3.4 & 1.11 & 1 & Medium \\
\hline
\end{tabular}

Table (4) shows that the arithmetic means ranged between $(2.72-3.72)$, where the item (10) states "The principal directs students to respect, appreciate and preserve books" ranked first with an arithmetic mean of (3.72) with a high degree. However, item (6), which states " The principal creates a group of students to enrich their knowledge of the site and the systems" ranked last with an arithmetic mean of (2.72) with a medium degree. The arithmetic means for the field of the school principal's role in developing good citizenship as a whole was (3.4), with a medium degree. This may be caused by the fact that school principals understand the important role played by books, resources, and references in achieving good citizenship, which motivates them to establish a modern library capable of meeting the requirements of both teachers and students seeking to reach a higher level of cultural development, but the financial reality that schools go through weaken the ability of the school principal to provide a continuous modern library for students. It is also due to the awareness of teachers that school administrations possess an awareness of the importance of school activities enhanced by teamwork among students and the impact of society on Islamic culture to give them different skills and increase their belonging to the community in which they live.

The school administration invites students to take care of the universal and legal ages through meditation and benefit from these years to raise their level of performance and the mechanism of benefiting from the available means and works to raise students positively so that they behave moderately by taking the reasons and not forgetting them, and developing their moral behavior where they acquire virtues, and move away from vices, as they demolish society. So, they must be urged to do good, be positive and cooperate, and to create an open personality interacting with society and with other civilizations. Also, the school administration must use mental capabilities and direct them to serve community life by educating students to observe and think critically and expand their intellectual frameworks.

The Second Area: the teacher's role in developing good citizenship

Table 5: Arithmetic Means and Standard Deviations related to the Teacher's Role in Developing Good Citizenship are in Descending Order by Arithmetic Means.

\begin{tabular}{|l|l|l|l|l|l|}
\hline $\mathbf{N o}$ & Item & AM & SD & Rank & $\begin{array}{l}\text { Degree } \\
\text { Agreement }\end{array}$ \\
\hline $\mathbf{1}$ & $\begin{array}{l}\text { The teacher organizes open discussions with students to learn } \\
\text { about their patterns of thinking about country and citizenship }\end{array}$ & 3.47 & 1.14 & 2 & Medium \\
\hline $\mathbf{7}$ & $\begin{array}{l}\text { The teacher represents the values of citizenship as a model to } \\
\text { guide students }\end{array}$ & 3.43 & 1.09 & 3 & Medium \\
\hline $\mathbf{5}$ & $\begin{array}{l}\text { The teacher develops the value of freedom of expression and } \\
\text { opinion away from hurting others }\end{array}$ & 3.42 & 1.13 & 4 & Medium \\
\hline $\mathbf{8}$ & The teacher develops patriotism in the hearts of students. & 3.39 & 1.17 & 5 & Medium \\
\hline $\mathbf{2}$ & $\begin{array}{l}\text { The teacher is keen on introducing students to the homeland and } \\
\text { its resources, and preserving its cultural achievements }\end{array}$ & 3.34 & 1.12 & 6 & Medium \\
\hline $\mathbf{6}$ & $\begin{array}{l}\text { The teacher communicates with and participates in the local } \\
\text { community }\end{array}$ & 3.31 & 1.13 & 7 & Medium \\
\hline $\mathbf{1 0}$ & $\begin{array}{l}\text { The teacher encourages students to engage in social solidarity } \\
\text { and help each other }\end{array}$ & 3.29 & 1.14 & 8 & Medium \\
\hline $\mathbf{1 1}$ & $\begin{array}{l}\text { The teacher provides students with the skills to interact with } \\
\text { others }\end{array}$ & 3.27 & 1.22 & 9 & Medium \\
\hline $\mathbf{3}$ & $\begin{array}{l}\text { The teacher promotes students' values of citizenship and } \\
\text { encourages devotion to them }\end{array}$ & 3.26 & 1.21 & 10 & Medium \\
\hline $\mathbf{9}$ & $\begin{array}{l}\text { The teacher develops pride in students 'Islamic and national } \\
\text { identity }\end{array}$ & 3.22 & 1.16 & 11 & Medium \\
\hline $\mathbf{4}$ & $\begin{array}{l}\text { The teacher prepares educational situations in which he } \\
\text { highlights the value of citizenship to students }\end{array}$ & 3.18 & 1.22 & 12 & Medium \\
\hline & Total average & 3.33 & 0.47 & 2 & Medium \\
\hline
\end{tabular}

Table (5) shows that the arithmetic means ranged between (3.18-3.47), where the item (1) states "The teacher organizes open discussions with students to learn about their patterns of thinking about country and citizenship" ranked first with arithmetic mean (3.47) with a medium degree. Yet, item (4), which states "The teacher prepares 
educational situations in which he highlights the value of citizenship to students" ranked last with a mean of (3.182) and a medium degree. The mean of the teacher's role in developing good citizenship as a whole was (3.33), with a medium degree.

This is attributed to the teachers 'awareness that the teacher is the most important figure in the educational system, so if his relations with his students are characterized by tolerance and honesty, they will contribute to the formation of the features of their personalities and their behavior, proving them with the educational and cognitive experiences and balanced cases of emotional stability and mental maturity. Thus, the teacher is the model whom the student sees every day and is affected by him, so the teacher must be a good example because students in adolescence need care, attention, and help in solving their school and family problems to achieve compatibility along with their needs for education and academic achievement.

The Third Area: the role of activities and courses in developing good citizenship

Table 6: Arithmetic Means and Standard Deviations related to the Role of Activities and Courses in Developing Good Citizenship are in Descending Order by Arithmetic Means.

\begin{tabular}{|l|l|l|l|l|l|}
\hline $\mathbf{N o}$ & Item & AM & SD & Rank & $\begin{array}{l}\text { Degree } \\
\text { Agreement }\end{array}$ \\
\hline $\mathbf{9}$ & Activities contribute to enhancing student citizenship & 3.41 & 1.09 & 1 & Medium \\
\hline $\mathbf{2}$ & $\begin{array}{l}\text { The curriculum shows the importance of the relations with } \\
\text { relatives }\end{array}$ & 3.38 & 1.15 & 2 & Medium \\
\hline $\mathbf{4}$ & $\begin{array}{l}\text { The curriculum promotes a culture of human communication } \\
\text { with others }\end{array}$ & 3.33 & 1.13 & 3 & Medium \\
\hline $\mathbf{5}$ & The curriculum promotes social programs. & 3.30 & 1.13 & 4 & Medium \\
\hline $\mathbf{7}$ & The curriculum contributes to solving community problems. & 3.29 & 1.13 & 5 & Medium \\
\hline $\mathbf{1}$ & $\begin{array}{l}\text { The curriculum encourages student participation in national } \\
\text { events. }\end{array}$ & 3.26 & 1.16 & 6 & Medium \\
\hline $\mathbf{1 0}$ & $\begin{array}{l}\text { Islamic values are promoted through the curriculum. } \\
\text { The curriculum contains lessons that contribute to } \\
\text { community service. }\end{array}$ & 2.99 & 1.09 & 8 & Medium \\
\hline $\mathbf{8}$ & $\begin{array}{l}\text { The curriculum is concerned with what educates students } \\
\text { about the righteousness of parents. }\end{array}$ & 2.98 & 1.25 & 9 & Medium \\
\hline $\mathbf{9}$ & $\begin{array}{l}\text { Curricula contribute to the development of duties towards } \\
\text { society. }\end{array}$ & 2.76 & 1.232 & 10 & Medium \\
\hline $\mathbf{3}$ & $\begin{array}{l}\text { The curriculum encourages students' participation in the } \\
\text { community awareness campaigns. }\end{array}$ & 2.72 & 1.20 & 11 & Medium \\
\hline & Total average & 3.14 & 0.47 & 1 & Medium \\
\hline
\end{tabular}

Table (6) shows that the arithmetic means ranged between (2.72-3.41), where the item (9) states "Activities contribute to enhancing student citizenship" ranked first with arithmetic mean (3.41) with a medium degree. Still, (3) which states "The curriculum encourages students' participation in the community awareness campaigns" ranked last with an arithmetic mean of (2.722) with a medium degree. The mean of the field of activities and courses in developing good citizenship as a whole was (3.14) with a medium degree.

The result of this field can be explained by the fact that those who prepare the study materials have a longterm vision to reach their desired goals to deepen good citizenship among students. Perhaps the reason for this is that the development of study materials is in line with the cognitive and technological inventions through the provision of appropriate study materials to preserve the values of good citizenship and fight against novel extraneous factors that destabilize the value system.

Results related to the second question: What are the obstacles that Jordanian high schools face in deepening good citizenship among their students from the standpoint of their teachers?

To answer this question, the arithmetic means, standard deviations, rank, and degrees for the study sample estimations for the obstacles facing Jordanian public high schools in deepening good citizenship have been calculated as shown in Table (7). 
Table 7: Arithmetic Means, Standard Deviations, Ranking and Degree of Study Sample Estimations of the Obstacles Facing Jordanian Public High Schools in Deepening Good Citizenship in Descending Order

\begin{tabular}{|c|c|c|c|c|c|}
\hline No & Item & $\mathbf{A M}$ & SD & Rank & $\begin{array}{l}\text { Degree of } \\
\text { Agreement }\end{array}$ \\
\hline 12 & $\begin{array}{l}\text { Departments fail to support programs that aim to serve the } \\
\text { community to develop citizenship values. }\end{array}$ & 4.56 & 0.63 & 1 & High \\
\hline 8 & $\begin{array}{l}\text { There is a lot of responsibility on the teachers that does not allow } \\
\text { the teacher to follow the conditions of their students. }\end{array}$ & 4.48 & 0.86 & 2 & High \\
\hline 2 & $\begin{array}{l}\text { Increasing the tasks assigned to the teacher hinders the follow- } \\
\text { up of students 'problems. }\end{array}$ & 4.37 & 0.76 & 3 & High \\
\hline 11 & $\begin{array}{l}\text { The school's failure to educate its students about the duties and } \\
\text { responsibilities towards the family and the community. }\end{array}$ & 4.36 & 0.71 & 4 & High \\
\hline 10 & Weak curricula to deepen good citizenship among students. & 4.32 & 0.70 & 5 & High \\
\hline 3 & $\begin{array}{l}\text { Adopting student's achievement as a primary variable in the } \\
\text { judgment of the teacher and not on his positive impact on student } \\
\text { behavior. }\end{array}$ & 4.31 & 0.77 & 6 & High \\
\hline 5 & $\begin{array}{l}\text { Adoption of traditional concepts (achievement and mark, } \\
\text { memorization and recalling), which constitutes a weakness in } \\
\text { the educational process. }\end{array}$ & 4.30 & 0.66 & 7 & High \\
\hline 1 & $\begin{array}{l}\text { Failure to link participation in activities related to social } \\
\text { responsibility and religious values. }\end{array}$ & 4.30 & 0.70 & 8 & High \\
\hline 4 & $\begin{array}{l}\text { Insufficient time during the course to discuss all values of } \\
\text { citizenship. }\end{array}$ & 4.26 & 0.68 & 9 & High \\
\hline 9 & $\begin{array}{l}\text { The lack of a clear approach to deepening the values of } \\
\text { citizenship in schools. }\end{array}$ & 4.26 & 0.70 & 10 & High \\
\hline 13 & Weak school programs related to good citizenship. & 4.24 & 0.60 & 11 & High \\
\hline 6 & $\begin{array}{l}\text { Lack of students' contribution to social work that contributes to } \\
\text { the promotion of citizenship. }\end{array}$ & 4.24 & 0.65 & 12 & High \\
\hline \multirow[t]{2}{*}{7} & The media's lack of encouragement to deepen citizenship. & 4.16 & 0.75 & 13 & High \\
\hline & Total average & 4.32 & 0.39 & & High \\
\hline
\end{tabular}

Table (7) shows that the total arithmetic means for the field of obstacles facing Jordanian secondary schools and their students were (4.32) with a standard deviation of (0.33) and a high degree, where the arithmetic averages ranged between $(4.16$ - 4.56). However, item (12) states "Departments fail to support programs that aim to serve the community to develop citizenship values" ranked first with an arithmetic mean of (4.56) and a standard deviation of (0.63) with a high degree. As for item (7) which states "The media's lack of encouragement to deepen citizenship" ranked last with an arithmetic mean of (4.16) and standard deviation of (0.75) with a high degree.

This may be because Jordan suffers from difficult economic conditions, which makes it unable to provide the necessary supplies to help schools activate their role in deepening good citizenship. Generally, the size of schools in Jordan suffers from the small size and the increase in the number of students in the classroom, which negatively affects its ability to allocate targeted facilities to deepen citizenship and social participation in it. It is also due to the lack of time for employees to attend seminars, courses, and conferences that would raise its performance career and be fully engaged with life and lack of time, which leads to a decline in their career level and the performance of the required tasks to the fullest.

\section{Recommendation}

In light of the aforesaid results, the following has been recommended:

- Create an appropriate learning environment that enables teachers to teach citizenship issues to students.

- Provide school libraries with awareness books and brochures that deepen and root the values of citizenship for dealing with all segments of society.

- Develop academic curricula to deepen the good citizenship of students and youth around the country: its history, geography, institutions, principles, regulations...... etc.

\section{References}

Aga, Suhaib and Assaf, Mahmoud. (2015). Educational administration and planning, Amman: Dar Al Janadriyah for Publishing and Distribution.

Asongu, J. (2007). The Legitimacy of Strategic Corporate Social Responsibility as a Marketing Tool, Journal of Business and Public Policy, 1(1): 12- 30.

Hassan, Mahmoud. (2013). The philosophy of citizenship among university students and the role of the university 
environment in supporting it in light of contemporary changes, unpublished Master Thesis, Mansoura University: Mansoura.

Issawy, Hamada. (2019). Contributions of social service to supporting the values of citizenship among high school students. Journal of Social Work,3, 59-85.

Janini, Naeem Habib. (2009). Contemporary sociology of education, Amman: Wael Press.

Khazaleh, Muhammad. (2010). The educational system between the Ministries of Education and Higher Education, Amman: Arab Society Library for Publishing and Distribution.

Martin, T. \& Yap, P. (2011). Civic and disparities: Exploring student's perceptions of citizenship within sing a pore's academic tracks. Theory and Researching Social Education, 39, 203-237.

Matar, Lubna. (2011). Evaluating the reality of school libraries in basic education in the city of Raqqa in Syria. Al-Fateh Journal, 46, 301-330.

Saadi, Ahmed. (2018). The role of the school in promoting the values of citizenship among middle school students in Makkah Al-Mukarramah. Journal of the Educational Association for Social Studies, 99, 127-153.

Sakran, Mohamed Mohamed. (2016). Education and cultural pollution: a critical analytical view. Journal of the Association of Modern Education, 8, 15-27.

Share, Adly and Abu Askar, Muhammad. (2017) The role of high school in Gaza Governorate in supporting citizenship aspects of its students from the viewpoint of humanities teachers. Journal of Scientific Research in Education, 12,564-535.

Shweihat, Safa. (2019). The role of colleges of educational sciences in Jordanian universities in developing the values of citizenship among students in light of some variables. Journal of Human and Social Sciences studies, $2,311-329$

Son, R. (2010). Citizenship in secondary in England. Research Paper in Education, 25, 457-478. 